\section{Søren Kierkegaard for fjerde gang! \\ En præsentation af den nye, kritiske udgave af Søren Kierkegaards samlede værker}

Af rektor, dr. phil. Else Marie Bukdahl, Det Kongelige Danske Kunstakademi

\section{10. oktober 1997 presenterede Soren} Kierkegaard Forskningscentret under Danmarks Grundforskningsfond de forste 5 bind af et af de storste videnskabelige udgivelsesprojekter, der nogensinde er päbegyndt $i$ Danmark, ved et festligt arrangement $i \mathrm{Ko}$ benhavns Universitets Festsal. Denne 4. udgave af Søren Kierkegaards samlede varker, der vil omfatte 55 bind, bygger ud over den trykte litteratur og forskning hovedsagelig $p a$ Kierkegaard-Arkivet i Det Kongelige Biblioteks Håndskriftafdeling, med hvilken Centret har indgået en sarlig samarbejdsaftale. I 1996 udgav de to institutioner i fallesskab bogen Skriftbilleder. Søren Kierkegaards journaler, notesbøger, hefter, ark, lapper og strimler (AfNiels Jorgen Cappelorn, Joachim Garffog Johnny Kondrup. Gads Forlag. 179 s.) og den store Kierkegaard-udstilling, der 1995 vistes $i$ Bibliotekssalen ved Rundetårn, har varet $i$ Paris og Berlin i 1996 og 1997. Ved presentationen holdt Diderot-forskeren og -udgiveren Else Marie Bukdahl nedenstaiende festforelesning om Udgaven.

I dag er der ingen, der er i tvivl om, at Søren Kierkegaard er blevet en lysende stjerne i den internationale verden. Både i øst og vest og i the Far East har hans forfatterskab længe været et uundværligt led $\mathrm{i}$ undervisning, $\mathrm{i}$ forskning og $\mathrm{i}$ kulturdebatten - helt på linie med f.eks. Platon, Luther, Kant og Hegel.

Interessen for Kierkegaards forfatterskab er dog blevet mærkbart intensiveret siden slutningen af 70'erne. Netop på det tidspunkt begyndte den marxistiske filosofi for alvor at miste sin tiltrækningskraft - senere fulgte de kommunistiske regimers fald. I dette omskiftelige tidehverv pejlede både øst og vest efter nye værdier og Kierkegaards forfatterskab blev en vigtig inspirationskilde. Hans tankeverden fik en ny og iøjnefaldende aktualitet. Det skyldtes måske især, at hans kristelige tilværelses- og menneskeforståelse på en enestående og original måde skaber et netværk af forbindelseslinier mellem det individuelle og det social-etiske og mellem det etiske og human-religiøse såvel som en afgrænsning mellem det religiøse og det kristelige.

De mange nydannelser i kunstens og litteraturkritikkens verden, der er dukket op i de sidste to decennier, har aktualiseret andre sider af hans forfatterskab og inspireret til nye tolkninger af hans digteriske diskurs og af hans originale bidrag til æstetikken. Hertil kommer, at Kierkegaard så afgjort også tilhører litteraturens verden. Han er en fornyer af dansk prosa på et højt kunstnerisk plan.

Denne afdækning af nye og aktuelle perspektiver i Kierkegaards tankeverden har medført, at manglen på en ny kritisk udgave af hans samlede værker, er blevet særligt mærkbar og har fàet 
en meget høj prioritet på de danske og udenlandske Kierkegaardforskeres ønskeliste.

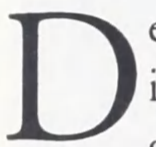

e ovennævnte synspunkter indgik $i$ et vidtforgrenet fletværk af argumenter, der resulterede i, at Danmarks Grundforskningsfond besluttede at oprette et Kierkegaardcenter med Niels Jørgen Cappelørn som leder. Det blev indviet i 1994. Dette center har nu i snart fire år arbejdet - koncentreret og målbevidst - med to delvis forbundne former for forskningsindsats, der dog har hver sit formål:

For det første: en overordnet og langsigtet forskningsindsats - i samarbejde med en videnskabelig komité der har det formål at fremme bestemte, aktuelle områder inden for Kierkegaards tænkning.

For det andet: tilvejebringelsen af en ny kritisk udgave af hele Kierkegaards samlede produktion, i bogform og i databaseversion.

\section{I dag har vi den meget store} glæde at kunne fejre de fornemme frugter af den sidstnævnte store forskningsindsats. Bogversionen af Kierkegaards samlede værker består af intet mindre end 28 tekstbind og 27 bind kommentarer. Den nye udgave kommer til at indeholde alt, hvad Kierkegaard har skrevet. Således både de skrifter, han selv lod trykke, og dem som han ønskede udgivet efter sin død eller ikke nåede at gøre færdig. Hertil kommer hans mange journaler, notesbøger, løse papirer samt forskellige breve og biografiske dokumenter. Den nye Kierkegaardudgave er redigeret af Niels Jørgen Cappelørn, Joa- kim Garff, Johnny Kondrup, Alstair McKinnon og Finn Hauberg Mortensen. De tre første tekstbind og de to kommentarbind, der ledsager dem, udkommer i dag. Det drejer sig om nye tekstkritiske udgaver af $A f$ en endnu levendes Papirer, Om Begrebet Ironi og første og anden del af Enten-Eller. Men vi fejrer ikke alene udgivelsen af disse fem perfekt redigerede bind. Vi fejrer også, at adskillige af de næste bind er på trapperne. Og der skal lyde et særligt tillykke til redaktionen, fordi den har udsendt en nøje tilrettelagt tidsplan, der klart markerer, hvornår de forskellige bind udkommer. Det er virkelig en sjældenhed! En sådan plan er utrolig vigtig for de mange Kierkegaardforskere, der naturligvis ønsker at bruge den nye udgave. De kan tilrettelægge deres arbejde efter tidsplanen. Eventuelle mindre forsinkelser betyder ikke noget. De store udgaver - f.eks. Hegeludgaven - har desværre ofte forsinkelser på flere år, hvad der altid resulterer i adskillige løvebrøl i forskningsverdenen.

At færdiggøre en ny kritisk udgave af et så stort og kompliceret forfatterskab som Søren Kierkegaards kan bedst sammenlignes med skabelsen af et isbjerg i de grønlandske fjorde. Det færdige værk svarer til den lille del af isbjerget, der med sine spidse og skarpe konturer stikker op af vandet. De uhyre tidskrævende og indviklede arbejdsprocesser, som en sådan stor udgivelse bygger på, svarer derimod til den kæmpestore, vidtforgrenede del af isbjerget, som ligger under vandet og som har mange farlige skær og mystiske hulrum og et labyrintisk netværk af forgreninger. 


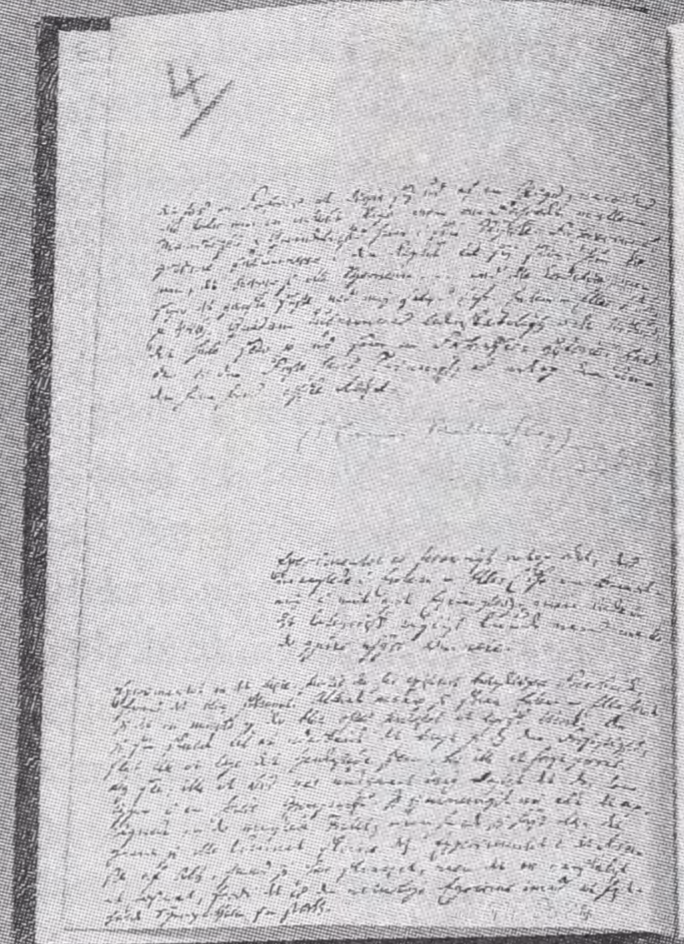

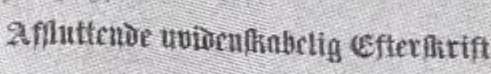

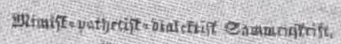

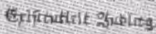

3oljannes elinaras

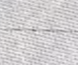

B. Hierfagdiat.

Alikhthjeva.

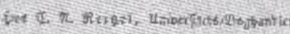

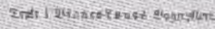

1446

Titelblad til Afsluttende uvidenskabelig Efterskrift til de philosophiske Smuler af Johannes Climacus, udgivet af Soren Kierkegaard, 1846, med forfatterens egne kommentarer på forsatsbladet.

Det er vel nok først og fremmest de, der selv er involveret i udgivelsesarbejde, der for alvor har blik for den enorme faglige indsats, en ny Kierkegaardudgave kræver. Det skyldes netop, at de mange tidskrævende arbejdsgange ikke er synlige de ligger under havets overflade.

Kierkegaards værker er før blevet udgivet. De tre udgaver af Samlede varker er imidlertid præget af en tekstkritisk optik, der var fremherskende i begyndelsen af århundredet, men som for længe siden er blevet forladt. Udgiverne undervurderede førstetrykket og valgte som grundtekst den sidste udgave fra forfatterens hånd. Hertil kom, at de rettede $\mathrm{i}$ teksten ud fra deres tids be- greber om korrekthed, ligesom de ændrede grundteksten og inddrog manuskripterne, når de mente, at Kierkegaards intentioner var bedre udtrykt dér. Derved fremkom der et tekstbillede, der havde flere, ofte vanskeligt dechifrerbare rødder og som i mange tilfælde byggede på et personligt skøn. Derfor blev teksten tit vanskelig at arbejde med.

Redaktørerne af den nye, helt komplette udgave af Søren Kierkegaards samlede skrifter anerkender naturligvis forgængernes indsats, men bygger selv på helt andre skarpe, konsekvente og kontrollerbare tekstkritiske principper. Udgivernes overordnede målsætninger er i overensstemmelse med den nyfilolo- 
8 giske opfattelse, der præger de store nye udgaver af f.eks. de tyske eller franske klassikere. Men redaktørerne af den nye Kierkegaardudgave har også ydet mange helt selvstændige bidrag til den aktuelle diskussion om tekst-kritik.

Deres overordnede og ufravigelige tekstkritiske standpunkt er at lægge Kierkegaards førstetryk til grund for deres udgave og alene rette i grundteksten, når der f.eks. optræder trykfejl og andre meningsfejl. Sådanne rettelser er omhyggeligt noteret $i$ et tekstkritisk apparat, der er anbragt nederst på siden, således at læseren med det samme kan tage stilling til dem. Ved helt konsekvent at bruge førstetrykket som grundlag får teksterne et ensartet præg og man undgår at blive præsenteret for en uigennemskuelig blandingstekst. Valget af førstetrykket har også en receptionshistorisk betydning, idet det var denne tekst, hvormed forfatteren første gang optrådte for sit publikum og fik indflydelse på sin samtid og nære eftertid. Det første bind af bogversionen af de skrifter, som Kierkegaard selv lod trykke, er forsynet med overskuelige og alligevel detaljerede retningslinier for de tekstkritiske principper, der er anvendt. Læseren får herigennem en helt klar forestilling om, hvilket tekstbillede, han står overfor. Sådanne retningslinier vil de bind, der rummer de tekster, som Kierkegaard ikke selv har bragt i trykken, og hans journaler og papirer også blive forsynet med. Bogen Skriftbilleder (1996), der er skrevet af Niels Jørgen Cappelørn, Joakim Garff og Johnny Kondrup, og som er spændende som en kriminalroman, giver et anskueligt indtryk af de mange vanskelige, men fascinerende problemer, som udgivelsen af Kierkegaards journaler, notesbøger, hæfter, ark, lapper, strimler og tegninger giver.

Men i modsætning til de tidligere udgaver af Kierkegaards værker, har redaktionen af den nye udgave givet bogversionen en søster. Det drejer sig om den elektroniske version, der er en fantastisk nyttig del af udgivelsesarbejdet. Den rummer også helt nye bidrag til løsningen af de problemer, som den moderne tekstkritik rejser.

Det er lykkedes redaktørerne at planlægge et computerprogram, der har gjort det muligt at lægge alle forarbejder til Kierkegaards trykte og ikke trykte skifter - f.eks. udkast eller korrekturer - ind under de forskellige skrifters færdige tekst. Sidstnævnte findes både i den elektroniske version og i den trykte udgave. Den elektronisk version er indrettet så sindrigt, at brugeren af den kan læse hvert tilblivelseslag $i$ et skrift horisontalt (fra den ene ende til den anden). Men det er også muligt at arbejde sig vertikalt ned gennem alle lag i skriftets tilblivelseshistorie. Endelig er andenudgaven af de skrifter, som Kierkegaard lod udgive i sin levetid og korrekturer hertil, ligeledes lagt ind i den elektroniske version. Læseren får således også mulighed for at få et overskueligt indtryk af, på hvad måde Kierkegaard har rettet sine tekster fra den første til den anden udgave.

Man kan med rette hævde, at den elektroniske version er den egentlige kritiske udgave af Søren Kierkegaards samlede værker, idet den tillader læseren at følge forfatterens arbejde med teksten 
fra det første udkast til den endelige version.

En sådan snart horisontal, snart vertikal rejse gennem alle de arkæologiske lag i teksten har imidlertid ikke alene tekstkritisk interesse. Den kan i mange tilfælde også føre til afdækning af nye nuancer og perspektiver $\mathrm{i}$ tolkningen af udviklingsfaserne i Kierkegaards tænkning og hans snart direkte, snart indirekte dialog med samtiden.

Også kommentarerne til den nye Kierkegaardudgave er en iøjnefaldende nydannelse. Der bliver skrevet nye kommentarer til alle tekster og der er tilstræbt en forbilledlig ensartethed såvel $i$ kommenteringens tæthed som i den sproglige udformning. Kommentatorerne har også taget hensyn til, at vor tid er præget af et historisk og poetisk hukommelsestab og at de efterhånden mange udenlandske Kierkegaardforskere, der læser dansk, har brug for en række særlige oplysninger. Kommentarerne oplyser - kort og præcist - om alle historiske og sproglige forhold, som kan volde den moderne læser vanskeligheder, men undgår omhyggeligt enhver form for tekstfortolkning. Netop derfor er de et glimrende redskab til at åbne teksten og stimulere til fortolkninger. Men kommentarerne afslører også på en meget konkret og tydelig måde, i hvor høj grad Kierkegaard hele tiden førte en dialog med samtiden, f.eks. med den tyske filosof Friedrich Schlegel. Disse vidtforgrenede dialoger har han indskrevet $\mathrm{i}$ sine tekster. Og derfor giver også studiet af kommentarerne anledning til nye tolkninger af Kierkegaards tænkning, især af dens af-hængighed af samtidens filosofiske opfattelser og det originale bidrag, han selv har ydet. Mængden af kommentarer er forøget mere end 50 procent i forhold til de tidligere udgaver. Derfor er de samlet i selv-stændige bind - $27 \mathrm{i}$ alt og de udgives altid sammen med tekstbindene. Denne disposition har medført, at tekstbilledet træder meget klart frem. Læseren kan ubesværet bruge kommentarbindene efter behov. En introduktion til det første bind af kommentarerne giver læseren en anskuelig forestilling om principperne for kommenteringen. Men hvert kommentarbind rummer også en meget nuanceret manuskriptbeskrivelse og en tilblivelseshistorie, der ofte er ledsaget af gengivelser af manuskripterne. Tre tekstbind og to kommentarbind udkommer i dag. Det er Bent Rohde, der har stået for den fornemme og stilsikre typografiske tilrettelæggelse af hele udgaven. Den er en fryd for øjet.

Både bogversionens tekst og kommentarerne er redigeret på en sådan måde, at ikke alene Kierkegaardforskeren, men også hvad Kierkegaard selv kaldte "den menige mand" med udbytte kan læse skrifterne. Det ville Kierkegaard uden tvivl have glædet sig over. Gennem sine mange spadsereture rundt i København, hvor han tit fik ideerne til sine værker, mødte han ofte "den menige mand". Han siger selv: "Du menige mand! Jeg har ikke afsondret mit liv fra dit; Du ved det; jeg har levet på Gaden, er kjendt af Alle; videre: jeg er ikke blevet til noget, tilhører ingen Stands-Egoisme: så hvis jeg tilhører Nogen, måtte jeg tilhøre dig, Du menige Mand."

Den nye udgave af Kierke- 
gaards skrifter rummer mange nye vigtige tekstfilologiske metoder og synspunkter og kan inspirere andre forskere til at gå i gang med nye tekstkritiske arbejder. Den kan også - f.eks. sammen med Det danske Sprog- og Litteraturselskabs fine udgaver - være med til at skabe bedre forståelse for vigtigheden af et grundigt tekstkritisk - og et grundigt kommenteringsarbejde. En sådan forståelse er mere udbredt i udlandet end herhjemme. Kierkegaardudgaven viser tydeligt, i hvilken grad det tekstkritiske og det tekstfilologiske arbejde er en meget vigtig forskningsgren, som 60 'ernes nymarxistiske metoder desværre havde stødt ud i kulissen, men som heldigvis igen er ved at indtage den plads i forskningsverdenen, som tilkommer den. Men udgivelsen af Kierkegaards skrifter afslører også, at det tekstfilologiske arbejde ikke foregår i et lukket rum. Det er nært tilknyttet optagetheden og fortolkningen af receptionshistorien og har mange perspektivrige referensrammer. Og derfor får det på mange niveauer betydning for selve tolkningen af Kierkegaards tænkning.

Og udgavens vigtigste funktion er naturligvis, at den kan inspirere til nye tolkninger af Kierkegaards skrifter og danne et solidt grundlag for dem. Kierkegaard-udgaven er ikke alene et helt uundværligt fundament til studiet af en forfatter, der er verdensberømt og indgår $\mathrm{i}$ forskning og undervisning $\mathrm{i}$ mange lande. Udgaven er også et nyt og vigtigt redskab til studiet af en original filosof, etiker og teolog og en stor prosaist, der mere end nogen sinde før er placeret i aktualitetens brændpunkt, og hvis tanker gribes begærligt af og har fået betydning for mennesker, der ikke tilhører den videnskabelige verden, men er optaget af at finde nye løsninger på vor tids filosofiske, etiske og æstetiske problemer, som er næsten uden fortilfælde. Det var Kierkegaards drøm at få netop denne betydning. Og også den er blevet opfyldt. Derfor har det vakt stor glæde i mange ofte helt forskellige miljøer i Danmark og i udlandet, at der efter så lang tid endelig er blevet taget initiativ til at skabe en nyfilologisk udgave af Kierkeyaards værker, ledsaget af nye kommentarer og en elektronisk version. $\mathrm{Og}$ glæden bliver endnu større, når det som nu - bliver muligt at læse de første bind - for slet ikke at tale om de følgende bind og fuldendelsen af værket.

Der er derfor mange grunde til at ønske den hårdt arbejdende redaktion af den nye Kierkegaardudgave tillykke med det fornemme resultat. Men der skal også lyde et tillykke til deres nærmeste medarbejdere fra Dansk Sprog- og Litteraturselskab, til Det Kongelige Bibliotek, til de mange kommentatorer og konsulenter samt til alle de Kierkegaardeksperter, der er eller har været $\mathrm{i}$ selve Kierkegaardcentret eller kommer fra danske og udenlandske institutioner og som på forskellige planer og i forskellige sammenhænge har været inddraget i udgivelsesarbejdet og fortsætter med at være det. Og til sidst skal der også rettes et stort tillykke til Gads forlag, der har stået for udgivelsen. 


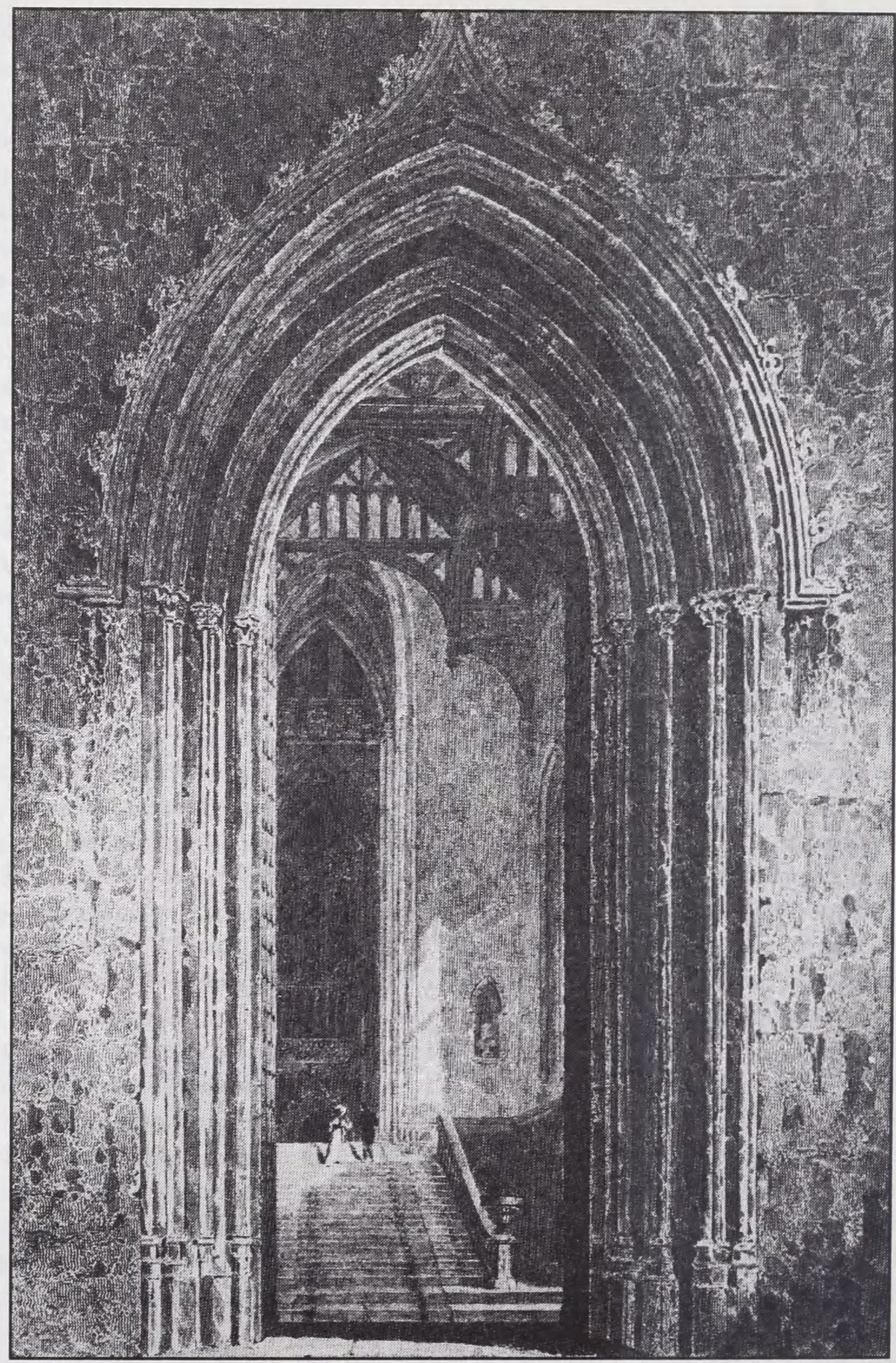

Fonthill: The Grand Staircase. Fra J.P. Neale's Views of the Seats of Noblemen and Gentlemen. 